\title{
Mobilizace proti levici? Stranické konsekvence volební účasti v kontextu postkomunismu
}

\author{
Michal Nový ${ }^{1}$
}

Text byl zpracován v rámci projektu specifického výzkumu Katedry politologie FSS MU "Volby, politické strany a prosazování zájmů" (kód MUNI/A/0742/2012).

\begin{abstract}
Mobilization Against the Left? Party Consequences of Voter Turnout in the Post-Communist Context

Does higher turnout support left-wing parties, as many previous studies assume? And does communist legacy somehow project on the mentioned relationship? The theoretical discussion is still relatively unclear. This study proposes three different explanatory mechanisms of examining aggregate-level relationship between turnout and electoral support for political parties in the post-communist milieu. The mainstream bypothesis, based on the assumptions of a successful re-stratification of the society and the relevance of class voting, states that higher turnout benefits the left. The second option is derived from the Michigan model of party identification. In this case, political parties with less loyal electorate should profit from higher rates of electoral participation. However, this article makes a case for a third possible explanation, which turns the conventional bypothesis upside down and can be termed simply as "mobilization against the left". The idea is that the more people come to the polls, the stronger the postcommunist right wing parties will be. Moreover, I include in my analysis only two electoral districts (regions) that can be said to be the farthest away from each other in their socioeconomic and political characteristics. Such an approach makes it possible to answer the question whether the expected effect is uniform or unequal across electoral districts in one country. Based on the analysis of election results in 1444 constituencies of two electoral districts in the Central Bohemian and Moravian-Silesian regions in the 2010 Parliamentary elections, I conclude that the proposed approach to the issue of party support and voter turnout has strong empirical support.
\end{abstract}

Keywords: Effect of voter turnout, 2010 Czech election, communist legacy, mobilization against left

\section{1. Úvod}

Vyšší volební účast favorizuje levici, protože se k urnám dostaví i voliči s nízkým sociálním statusem. Malý počet příchozích voličů zase podporuje extrémní strany, jelikož voličské jádro těchto stran je neobvykle pevné, ovšem nemá se kam rozpínat. Po každých volbách slýcháváme z fundovaných analýz tyto (a nejen ty) předpoklady o efektu volební účasti na zisky politických stran. Je ale možné nahlížet na očekávané účinky volební účasti s takovým zjednodušením? Odpovědět lze ambivalentně: $\mathrm{Na}$ jednu stranu bezesporu lze prověřovat platnost takto postavených hypotéz, ovšem na straně druhé se může zdát obohacující brát v potaz specifický kontext určitého území, v němž se koná soutěž politických stran. Ten by mohl vést k precizaci

\footnotetext{
1 Michal Nový působí jako prezenční doktorand na Katedře politologie Fakulty sociálních studií Masarykovy univerzity a jako student navazujícího programu Regionální rozvoj na Mendelově univerzitě v Brně. Korespondenční adresa: Joštova 10, Brno, e-mail: 273880@mail.muni.cz.
} 
poměrně nejasné př́íinné souvislosti míry volební participace a potenciálu subjektů ve volebním klání.

V této studii se pokouším nahlížet na předpoklady teorií vlivu volební účasti na zisky stran s účelem zjistit, do jaké míry mohou být regionálně podmíněné. Do zkoumání zahrnuji jen určité sekce národní volební arény, což představuje poměrně zásadní badatelskou výzvu, která však v českých, ale ani zahraničních studiích doposud nebyla zvlášt' reflektována. Ve svém textu budu podrobovat analýze dvě regionální výseče národní arény, Středočeský a Moravskoslezský kraj, a to ve volbách do Poslanecké sněmovny z roku 2010. Takový výběr krajů ospravedlňuji s inspirací v argumentu Millovy metody shody ${ }^{2}$ (Lijphart 1971; Čechák 2006: 50-51): Socioekonomický i politický kontext těchto území se sice výrazně liší (v rámci České republiky se de facto jedná o nejvíce rozdílné případy ${ }^{3}$ ), avšak zároveň - a blíže to ozřejmím formulováním hypotéz v následujících odstavcích - předpokládám jednotné působení volební účasti na stranickou podporu.

Zvolil jsem klasický, i když poměrně silně kritizovaný přístup, kdy budu odkrývat kauzální vztahy pomocí dat na agregované úrovni. Ambicí práce je určit, do jaké míry ovlivňuje výše volební participace podíly hlasů pro různé politické strany ve dvou zmíněných volebních krajích, a tím bud’ zpochybnit, anebo podpořit platnost níže stanovených teoretických předpokladů. K modelování závislosti budu používat běžně využívaný statistický aparát - mnohonásobnou lineární regresi (blíže Hendl 2009: kap. 10). Jak naznačuji výše, jako problematické se může jevit riziko falešné inference plynoucí z práce s „nadindividuálními“ daty (Kostelecký, Čermák 2003). To se snažím minimalizovat sestoupením na co nejnižší úroveň agregace - za jednotku zkoumání budu považovat obec.

\section{Teorie vlivu volební účasti na zisky jednotlivých stran}

Literatura, která zkoumá volební účast jakožto nezávislou proměnnou, obvykle pracuje s rozlišením tř́ typů občanů, kteří jsou oprávněni vybírat své zástupce do veřejných úřadů. Jedná se notorické voliče (core/ habitual voters), př́ležitostné voliče (occasional voters) a principiální nevoliče (perpetual non-voters) (např. Campbell et al. 1960: 96-115; Grofman et al. 1999; Fisher 2007). Zatímco o notorických voličích se konstatuje, že hlasují vždy a ve všech typech voleb, u principiálních nevoličů se šance, že se zúčastní kteréhokoli hlasování, redukuje na minimum. Další analýza se zaměřuje téměř výhradně na druhou jmenovanou skupinu voličů, tj. na př́ležitostné voliče, kteří přicházejí do volební místnosti sporadicky. Jejich preference jsou klíčem ke tvorbě níže uvedených hypotéz. Jako závěr řady analýz, které se zabývají elektorátem, bývá uváděno, že neprivilegovaní a chudí voliči, tedy marginalizované segmenty s limitovanými zdroji, mají menší šanci hlasovat (mj. Brady et al. 1995; Teixera 1992), i když hranice mezi pozicí voliče a nevoliče v sociální struktuře se nezdá být nikterak robustní (Tóka 2004: 4). Účast takových voličů na soutěži je podmíněna okolnostmi a může s sebou prinést významné změny $\mathrm{v} z$ ziscích politických subjektů.

$\mathrm{Na}$ tom, jestli existuje určitý univerzální vzorec, který mapuje, jak ovlivňuje zvyšování, popř. snižování volební účasti volební performanci stran nebo kandidátů, však nepanuje př́lišná shoda.

\footnotetext{
${ }^{2}$ Je iluzorní domnívat se, že tento text zcela naplňuje kritéria Millovy metody shody, která lze přiblížit následovně: Jestliže mají dva př́pady jednoho fenoménu pouze jednu společnou vlastnost (a vše ostatní je rozdílné), pak tato vlastnost je příčinou nebo důsledkem. Tento předpoklad lze v empirických studiích obecně velmi těžko splnit.

${ }_{3}^{3}$ Prahu vzhledem ke statusu hlavního města nezapočítávám do potenciálních jednotek pro výběr, přestože oficiálně je samostatným krajem (srov. Illner et al. 2007: 974).
} 
Podle Fishera (2007) změna ve volební účasti v evropských multipartistických systémech (na rozdíl od bipartismů) často prínáší „kompletně nepředvídatelný efekt“, Rose (1997) zase argumentuje, že efekt volební účasti se přeceňuje a př́ležitostní voliči se preferencemi příliš neliší od pravidelně volící populace. Arend Lijphart (1997) pak připomíná, že charakteristiky volebních absentérů nejsou $\mathrm{v}$ jednotlivých kontextech totožné, a tudíž je prakticky nemožné stanovit uniformní kauzální mechaniku mezi volební účastí a potenciálem soutěžitelů.

I přes výše zmíněnou skepsi řada autorů nehodlá rezignovat na vytváření předpokladů o závislosti obou zmíněných proměnných. Výše volební účasti z jejich pohledu opravdu může napovědět, „kdo by mohl vyhrát a kdo prohrát“ (Hajnal, Trounstine 2005). Za velmi prínosnou lze v tomto ohledu považovat studii Paceka a Radcliffa (1995), která se inspiruje v průkopnické práci DeNarda (1980). DeNardo v prostředí amerických voleb pracoval s hypotézou, že vyšší volební účast podpoří zisky Demokratů, a to proto, že příležitostní voliči se spíše identifikují s Demokratickou stranou. Jinak řečeno, „Demokraté jsou tradiční šampióni chudých a neprivilegovaných“ (cit. dle Grofman et al. 1999: 358). ${ }^{4}$ Bráno touto optikou, marginalizované segmenty, jež se účastní voleb nepravidelně, ovšem principiálně se nezrríkají možnosti hlasovat, by měly vykazovat silnější náklonnost $\mathrm{k}$ levici (Radcliff 1994). Nevýhodou pro jimi preferovanou stranu je, že volí v nižší frekvenci než jejich lépe situovaní protějšci, kteří spadají do kategorie př́iznivců středových nebo pravicových stran. Jelikož př́ležitostní voliči mají být nepoměrně více levicově orientovaní, lze logicky dovodit předpoklad, že vyšší účast stimuluje úspěchy stran nalevo od středu politického spektra ${ }^{5}$ (Pacek, Radcliff 1995; 2003; viz také Lijphart 1997; Lutz, Marsh 2006; Hansford, Gomez 2010). Klíčovým tématem však je, jestli se v současné situaci vyšší volatility a nejasné sloupovité struktury lze opřít o předpoklad loajality nízkostatusových voličů k levici (Knutsen 2006: kap. 1). Míra opory tak přímo závisí na rezonanci socioekonomické konfliktní linie. ${ }^{6}$ Ve společnostech, v nichž lze doposud identifikovat sociální tř́dy, může argument vysvětlující vyšší zisky staré ${ }^{7}$ levice na základě různosti volební účasti fungovat (viz také Aguilar, Pacek 2000). ${ }^{8}$

\footnotetext{
${ }^{4}$ Sám DeNardo (1980) však dává svému článku podtitul „The Joke’'s on the Democrats“, což do značné míry napovídá, že se staví skepticky ke konvenční hypotéze o pozitivním vlivu vyšší účasti na zisky Demokratů. Mimo jiné i kvůli tzv. efektu defekce, který představuji v následující kapitole.

${ }^{5}$ Výzkumné pole vztahu volební účasti a výstupů soutěže o mandáty je však mnohem širší. Např. Hansford s Gomezem (2010) přidávají k tzv. stranické hypotéze (uvedené výše) další tři předpoklady vztažené k politické situaci ve Spojených státech: 1) Čím více Republikánů v elektorátu, tím víc při zvyšování účasti roste zisk Demokratů, a naopak, v obzvláště demokratických elektorátech vede vyšší volební účast ke snížení zisku Demokratů; 2) vyšší volební účast snižuje zisky stran, které aktuálně působí ve vládě; 3) s tím, jak roste volební účast, se volební zisky stávají méně předvídatelné.

${ }^{6}$ Vztáhneme-li tento požadavek na situaci před volbami do Poslanecké sněmovny 2010, můžeme tvrdit, že ekonomická témata byla na prvních místech, což podporuje domněnky o velmi silné rezonanci cleavage vlastníci versus pracující (SC\&C a SPSS CR 2010).

${ }^{7}$ Postmaterialisté nejsou v Pacekově a Radcliffově pojetí považováni za levici, která by byla zasažena efektem volební účasti.

${ }^{8}$ Detekce takto postaveného kauzálního vztahu mezi účastí a ziskem strany (tzv. partisan bias effect) se však může jevit velmi problematicky. Poměrně silné pochyby vyvolávají zejména Grofman a kolegové (1999), když k tomuto efektu předkládají dvě alternativní vysvětlení. Ve světle DeNardovy práce (1980) z amerického prostředí tvrdí, že 1) vyšší účast nemusí být prímo korelována se zisky Demokratů, nýbrž se stranou, která momentálně obsazuje čelo soutěže tzn. vyšší účast prospívá Demokratům pouze v situaci, kdy mají náskok na prvním místě a projevuje se tzv. bandwagoon efekt, anebo 2) v situaci, kdy Demokraté působí jako vyzyvatelé držitelů úřadu, kteří produkují zjevné omyly (competition effect) (srov. Tucker, Vedlitz 1986).
} 


\section{Mechanika fungování v prostředí postkomunismu}

Závojem pochybností zůstává zahaleno, jak interpretovat vztah mezi volební účastí a podporou politických stran pro postkomunistické společnosti. Volební participace v předstíraných demokraciích Východního bloku byla občanům desítky let nakazována, přestože z formálního hlediska nefungoval institut volební povinnosti (Birch 2009). Po pádu těchto režimů a „momentu velkého dramatu“ v mezidobí prvních svobodných voleb nastal výrazný propad ve volební účasti. Zkušenost nucené politické angažovanosti v éře demokratické fasády způsobila nechut' k politice a nově nabytá svoboda účastnit se politiky byla občany chápána jako svoboda „konečně“ neparticipovat (Vráblíková 2009; Rose 2009).

Postkomunistické společnosti se od západoevropského standardu liší také svou tř́dní strukturou, která byla $\mathrm{v}$ prostředí nedemokracie od základů přeměněna. Kvůli uplatňování rovnostářského př́stupu např. neplatilo, že vzdělaní lidé zároveň byli lépe situovaní než dělníci. Vznikla tak unikátní skupina „vzdělaných-chudých“. Nelze však odmítnout, že by pozdèjší transformační epocha nepřinesla novou strukturaci společnosti. Rovnostářská idea byla překonána tržními principy, sociální nerovnosti narůstaly, a společnost nabývala nových kontur. Průběh transformace nicméně nevrátil členění společnosti do intencí před érou nedemokracie, spíše vymezil dva nové tábory - skupinu těch, kteří na transformaci získali (vítězové), a ostatní (poražené), přičemž tyto segmenty nemusí odpovídat Rokkanově konfliktní linii vlastníci versus pracující (Hloušek, Kopeček 2005).

Někteři autoři tvrdí, že nově založené politické strany v postkomunistických společnostech do značné míry reprezentují konfliktní linie odpovídající těm, které se dají identifikovat v západních státech (Gijsberts, Nieuwbeerta 2000). Po pádu nedemokracií má ve středovýchodní Evropě docházet $\mathrm{k}$ procesu restratifikace společnosti, v níž se po dlouhém období vnucené nivelizace znovu posiluje sociální identita založená na sociálně-ekonomickém statusu a tř́dě (Smith, Matějů 2011). ${ }^{10}$ Otázkou ovšem zůstává, do jaké míry krystalizace tř́́dní struktury v nových demokraciích hraje úlohu prí formování politiky. Protože se po dobu prribližně čtyřiceti let nekonaly svobodné volby a reálně neexistoval multipartismus, řada voličů, zejména těch socializovaných v době nedemokracie, není schopna dostatečně ohodnotit prezentované politiky jednotlivých stranicko-politických aktérů s ohledem na svůj „objektivni“" status (srov. např. Torcal, Mainwaring 2003; Tóka 1996). ${ }^{11}$ Chápat volební chování v kontextu nových demokracií prvoradě jako třídně podmíněné se tak nemusí jevit jako úplně adekvátní řešení, přestože konkrétně na českém prrípadě badatelé empiricky dokázali, že vliv tř́dní příslušnosti na chování voličů po Sametové revoluci posiloval (viz Smith, Matějů 2011).

Při hledání mechanismu, na jehož bázi by šlo „nejlépe“ narýsovat vstupní předpoklady, se ovšem nemusíme omezovat pouze na objektivní umístění voliče v sociální struktuře, který má být dle tř́́dního hlasování klíčovým faktorem toho, jak jedinec hlasuje. Nabízí se také zaměření na

\footnotetext{
9 Sarah Birch (2009: 4-5) v této souvislosti hovoři o tzv. neformální volební povinnosti. Přestože návštěvu volební místnosti přímo nenakazoval zákon, z neparticipace vyplývaly sankce, typicky třeba ztráta možnosti pracovního postupu.

${ }^{10}$ Při úplném respektování těchto poznatků by se zdálo jako adekvátní vycházet z konvenční hypotézy hovořící o tom, že vyšší míra volební participace napomáhá vyšší podpoře levicových stran.

${ }^{11}$ Někteří autoři však toto konstatování odmítají (Plasser et al. 1998). I ve svébytném prostoru nových demokracií má docházet k tomu, že občané, kteří spadají do méně privilegovaných segmentů společnosti, upřednostňují strany s vyšší ochranářskou rolí vưči tržním silám. Exkomunistické strany, ale i sociální demokraté tím pádem oslovují mnoho př́znivců mezi pracující třídou a seniory. Má platit rovněž to, že stejně jako v rozvinutých demokraciích i v postkomunistickém prostoru panuje vyšší míra volebního absentování u sociálně znevýhodněných skupin (Bohrer et al. 2000).
} 
subjektivní motivace k preferenci určité stranické alternativy. Již v pionýrské práci DeNarda (1980) se zdůrazňuje kontradiktorní poloha dvou aspektů, které ovlivňují vztah mezi volební účastí a podporou toho či onoho politického aktéra. Jde o efekt struktury a efekt defekce. Prvně jmenovaný zrcadlí hledisko trúdního hlasování; představil jsem ho výše. Dále se proto budu obšírněji věnovat efektu defekce. Ten je možno chápat jako určitou výzvu efektu kompozice, která si bere inspiraci v teorii stranické identifikace. Stranickou identifikaci lze zjednodušeně chápat jako silnou a časově stabilní citovou vazbu jedince $\mathrm{k}$ některé straně, založenou z větší části v období politické socializace, která s sebou přináší zvyk loajality (Campbell et al. 1960: 121-122). Stranická identifikace může vzniknout bez ohledu na objektivní sociální status, čímž se zřetelně odlišuje od tř́dního hlasování. Koncept defekce pak vychází z toho, že voličské základny politických stran mají různou míru zastoupení silně identifikovaných (jádrových) voličů. Tím pádem mohou některé stranicko-politické subjekty tratit na tom, že jejich voliči sice vykazují loajalitu, ale ta je v převážné většině slabá.

S rostoucí participací na volebním klání by se přitom logicky měl zvyšovat počet voličů, kteří jsou méně loajální ke své straně, což může výrazně promlouvat do vztahu mezi volební účastí a zisky politických stran. Představme si třeba situaci, kdy statistický úřad vyhlásí, že účast v těch či oněch volbách byla vysoce nadprůměrná. Z hlediska kompozitního efektu by to znamenalo, že levice vyjde z takových voleb velmi silná, nebot' se dostavili i núzkostatusoví voliči. Ovšem v př́padě, že převáží efekt defekce, mủže dojít k tomu, že přes vysokou účast zvítězí pravicové strany, a to $\mathrm{v}$ důsledku vysoké míry defekce málo loajálních levicových voličů k pravicovým stranám.

Efekt defekce tak zavádí do vztahu mezi účastí a podporou stran další rovinu poznání. V této kapitole jej uvádím proto, že pro fungování politiky v nově demokratizovaných zemích je koncept stranické identifikace, z něhož tento efekt vychází, na rozdíl od západní Evropy celkově velmi obtížně uchopitelný. Většina postkomunistických voličů neměla vobdobí vlastní socializace šanci utužovat afektivní vazbu s jinou než komunistickou stranou. Politické strany vzniklé po kolapsu režimu lze chápat jako málo zavedené, a na hlubší identifikování zatím bylo relativně málo času. Ač voliči v kontextu postkomunismu mohou jen těžko nabývat podobného typu identifikace jako v západních demokraciích, byl teoretický rámec stranické identifikace k precizaci vztahu mezi volební participací a zisků stran v kontextu postkomunismu již využit (např. Linek 2012), a to i ve světle toho, že se ukázalo, že přes krátkou demokratickou epochu si řada voličů dokázala jistou formu psychologické vazby k některé ze stran vytvořit ${ }^{12}$ (Vlachová 2003).

V tomto textu nicméně vyjdu ještě z jiné formy „postkomunistické interpretace“ souvislostí mezi volební účastí a podporou politických stran. Celkové vnímání levice se totiž v kontextu postkomunismu zdá být velmi zvláštní. Po druhé světlové válce mohou být komunistické strany zemí Východního bloku jen obtížně ztotožňovány se západoevropskými uskupeními, která prrinejmenším v některých prrípadech (Itálie, Francie aj.) postupně konvergovala $\mathrm{k}$ demokratické soutěži o parlamentní většinu (Hloušek, Kopeček 2010). Učebnicový př́klad specifik východoevropské politiky nacházíme $\mathrm{v}$ českém prostředí, kde z pozice KSČM nedošlo ke

\footnotetext{
$12 \mathrm{Na}$ českém prrípadě by pak šlo odvodit hypotézy, že politické strany, jejichž elektorát je tvořen ve větší míře silně identifikovanými voliči (ODS, KSČM a KDU-ČSL), mají vyšší podporu při nižší volební účasti. Naopak stranickopolitičtí aktéři, mezi jejichž voliči převažují méně identifikovaní jedinci (ČSSD a nově ustavené strany jako TOP09, VV apod.), získávají vyšší podporu s vyšší volební účastí (Linek 2012: 5).
} 
zřeknutí se komunistického ideově-kulturního patrimonia a přerodu ve stranu demokratického socialismu (Kubát 2003: kap. 9).

Z tohoto úhlu pohledu se i já domnívám, že mechanismus vlivu volební účasti na zisky stran může pracovat na západní poměry poněkud neobvyklým způsobem. Podmíněnost efektu je dána stigmatem komunistické minulosti, které si s sebou levicové strany nesou bez ohledu na fakt, jestli v dobách nedemokracie existovaly, anebo nikoliv. Postkomunistická levice může na vyšší volební účasti paradoxně tratit, a to $\mathrm{v}$ důsledku občanské mobilizace „proti návratu starých pořádkư“, vyvolávané ze strany pravé části politického spektra. Především v době volebních kampaní bývá tento arzenál hojně využit a subjekty politické levice jsou rámovány jako potenciální hrozba pro fungování mladé demokracie ${ }^{13}$ (Matušková 2006).

Zatížení vyprodukované událostmi $\mathrm{v}$ minulosti se s levicovými uskupeními $\mathrm{v}$ postkomunistickém prostoru táhne, přestože dnes $\mathrm{v}$ drtivé většině reprezentují aktéry spadající do standardního demokratického rámce a obdobně jako v rozvinutých demokraciích je lze chápat jako obránce sociálně znevýhodněných (Bohrer et al. 2000). Ve shodě s Tókou (2004) se přikloním $\mathrm{k}$ tomu, že kauzální mechanika funguje tím způsobem, že zatímco $\mathrm{v}$ zavedených demokraciích levice $\mathrm{z}$ vyšší míry volební účasti těží, v postkomunistickém prostoru jí naopak vůbec neprospívá. Naznačený př́istup může být zjednodušeně prezentován pomocí výmluvného hesla „Mobilizace proti levici“" nebo se dá vyjádřit následujícími hypotézami:

$\left(\mathrm{H}_{1}\right)$ V podminkách vyšši volebni účasti budou vykazovat vy̌̌š procentuálni zisky blasu strany strèdu a pravice,

a také naopak:

$\left(\mathrm{H}_{2}\right)$ V podminkách vyšši volebni úcasti budou vykąovat nižš̌ procentuálni ziskey blasu strany levice. ${ }^{14}$

\section{Data a metody}

Většina prací, které zkoumají vztah volební účasti a podpory stran, se bud' usazuje do formátu cross-national (např. Pacek, Radcliff 1995), nebo zkoumá izolovaně situaci v jediné zemi (Tucker, Vedlitz 1986). Mimo to se objevují rovněž texty, které analyzují nižší než národní úroveň

\footnotetext{
${ }^{13} \mathrm{~V}$ českém prostředí bylo heslo „Mobilizace proti levici“ využito např. ODS a jejím tehdejším předsedou Václavem Klausem ve volební kampani před mimořádnými volbami do Poslanecké sněmovny v roce 1998. V podobném duchu se nesla i kampaň strany v roce 2002 či 2006.

${ }^{14}$ Nelze úplně opomenout, že efekt volební účasti na zisky stran může být víc selektivní, než bylo uvedeno v odstavcích výše (přehledně Linek 2007). Pro tuto studii by mohly mít význam třeba předpoklady nizozemských autorů van der Eijka a van Egmonda, kteří přikládali důraz faktoru ideologické teploty stran. Jakožto př̀edstavitelé konvenčního západoevropského směru přicházejí s tvrzením, že nižší volební účast znamená vyšší podporu pouze umirněným pravicovým stranám, nicméně v př́padě krajně pravicových stran jsou zisky nižší. Obdobně na levé straně spektra vede nižší volební účast k nižším ziskům umírněně levicových stran, ale krajně levicové strany získávají více (van der Eijk, van Egmond 2006: 14; Finseraas, Vernby 2011). Stranicko-politická uskupení, která působí na okrajích spektra, tak do jisté míry zpochybňují původní představy o uniformním vlivu volební účasti na celý blok pravice či levice. Ve světle faktu, že od dob vnitřního rozkladu SPR-RSČ nepůsobí v dolní komoře českého parlamentu žádný subjekt s čirou krajně-pravicovou identitou (o umístění VV na pravolevém kontinuu viz níže), by bylo možné zabývat se pouze rozdílností vlivu volební účasti na podporu sociálních demokratů a komunistů. V případě KSČM se můžeme přiklonit k tomu, že jádro této krajně-levicové formace se nemá kam rozpínat. V podmínkách vyšší volební účasti tedy může být negativní efekt volební účasti na zisky krajní levice podstatnější než negativní efekt na zisky umírněné levice (srov. Eibl et al. 2009: 121-123).
} 
stranické soutěže (Nagel, McNulty 1996; Saglie et al. 2012). Můj text stojí na pomezí druhé a třetí varianty. Bude zkoumat situaci v jedné zemi (Česká republika) a jedněch volbách (volby do Poslanecké sněmovny 2010), ovšem pouze v určitých regionálních výsečích dané volební arény ( $\mathrm{k}$ pojmu Strmiska et al. 2009) - ve Středočeském a Moravskoslezském kraji. V těchto volebních krajích spatřuji nejvíce kontrastní prípady, a to jak z hlediska socioekonomických charakteristik (viz Český statistický úřad 2011; 2012; srov. Blažek, Csank 2007), tak politického kontextu (Kouba 2007; Navrátil 2010). Již v úvodu jsem ovšem uvedl, že budu předpokládat, že směr i intenzita výše předpokládané závislosti by v těchto celcích měly být totožné. Pro lepši ilustraci přináším srovnání zvolených krajů v tabulce 1 . Tento poukaz regionální disparity rozhodně nemá představovat snahu o komplexní výčet rozvojových měřítek (srov. např. Svatošová 2004), nicméně $\mathrm{v}$ něm prezentuji snadno dostupná a dobře interpretovatelná data na úrovni kraje. Jelikož cílem textu není zevrubně popisovat regionální rozdíly, omezím se jen na několik stručných postřehů k veličinám $\mathrm{v}$ níže uvedené tabulce.

Tabulka 1. Regionální disparity

\begin{tabular}{lll}
\hline & Středočeský kraj & Moravskoslezský kraj \\
\hline Socioekonomický rozvoj & & 293281 \\
HDP na osobu v Kč & 319081 & 82,3 \\
HDP na osobu (ČR = 100) & 89,5 & -2875 \\
Migrační saldo & +14365 & 12,1 \\
Nezaměstnanost & 7,2 & 40,4 \\
Průměrný věk obyvatel & 40,0 & 0,19 \\
Ekonomické subjekty na 1 obyvatele & 0,23 & Př́hraniční, periferní \\
Typ regionu & Vnitrozemský, centrální & \\
Sídelní struktura & & 4178 \\
Průměrná velikost obce (obyv.) & 1083 & 41 \\
Počet obcí se statusem města & 81 & 75,8 \\
Podíl městského obyvatelstva & 54,0 & 229,9 \\
Hustota zalidnění & 113,3 & \\
Politický kontext & & 27,48 \\
Podpora pravici & 41,46 & 41,74 \\
Podpora levici & 31,52 & \\
\hline
\end{tabular}

Zdroj: Autor na základě dat Českého statistického úradu (2012). ${ }^{15}$

Zaprvé existují velmi silné diskrepance v úrovni socioekonomického pokroku obou regionů. Vyplývá to nejen z klasických ukazatelů ekonomického růstu, jako jsou relativní HDP a míra nezaměstnanosti, ale také $\mathrm{z}$ ukazatelů sociálního rozvoje. V tabulce využívám pro postihnutí sociální dimenze migrační saldo, které je rozdílem mezi přistěhovalými a vystěhovalými a může indikovat „atraktivitu“ regionu. Zatímco Středočeský kraj disponuje nejvyšší mírou čisté migrace (dokonce i vyšší než Praha), Moravskoslezský leží na opačném konci meziregionálního srovnání. Velkou důležitost přikládám rovněž kvalitativnímu typu regionu. Jak uvádějí Blažek s Csankem (2007), význam Prahy daleko překračuje její administrativní hranice, z čehož velmi těží právě

\footnotetext{
${ }^{15}$ Ukazatele socioekonomického rozvoje a sídelní struktury jsou za rok 2009. Výjimkou je nezaměstnanost, která byla sesbírána za duben 2010. Měřítka politického kontextu charakterizují kraje ve volbách do Poslanecké sněmovny 2010; pravici představuje součet volební podpory pro ODS a TOP09, levici pak součet zisků ČSSD a KSČM.
} 
Středočeský kraj. Naproti tomu Moravskoslezský kraj je př́hraniční oblastí se strukturálními problémy, jejichž základ tkví v éře komunistického zpo̊sobu modernizace (k pojmu Rose 2009).

Zadruhé mají oba kraje velmi specifickou sídelní strukturu. Přestože v obou regionech žije kolem 1,2 milionu obyvatel, jejich rozprostření po území vykazuje zásadní nesoulad. Symptomatickým rysem Moravskoslezského kraje jsou lidnatá sídla, oproti tomu Středočeský kraj je tvořen souborem menších měst a vesnic. Průměrná populační velikost moravskoslezské obce je takřka čtyřnásobná oproti středočeské; velké rozdíly se ovšem ukazují také v podílu urbanizace a hustoty zalidnění.

Konečně zatřetí, Středočeský a Moravskoslezský kraj z hlediska volebních výsledků náleží do dvou odlišných kategorií. Zatímco prvně jmenovaný představuje do značné míry „,volební baštu“ pravicových stran, ten druhý by zase šlo bez větších okolků prriřadit do kategorie těch regionů, které jsou klíčové z hlediska zisku mandátů levicových stran. Srovnání v tabulce 1 ukazuje, že dvojice ODS - TOP 09 získala v součtu o taǩrka 14 \% více hlasů ve středních Čechách než na severu Moravy. V př́padě dvojbloku ČSSD - KSČM je pak propast mezi volební podporou v obou krajích príbližně desetiprocentní.

\section{Operacionalizace proměnných}

Z pohledu cesty prověrování vztahů je možno vybrat si ze dvou stěžejních prrístupů: Bud' lze práci založit na zkoumání individuálních dat pocházejících ze sociologických šetření (Citrin et al. 2003), anebo následovat postup práce s agregovanými daty. Je třeba zmínit, že tento text je založen výhradně na analýze kumulovaných dat, a to prostřednictvím lineární regrese. Jak připomínají Grofman a kolegové (1999), pět nejvýznamnějších studií diskutujících stranické konsekvence volební účasti (mj. se jedná o DeNardo 1980 či Tucker, Vedlitz 1986) se spoléhá na agregovanou úroveň a korelační logiku. ${ }^{16}$ Práce s agregovanými daty přináší úskalí, pro které se např. Linek (2012) rozhodl agregovanou úroveň zcela opustit a soustředit se výhradně na individuální datovou bázi. Jedná se o problém nepřesnosti ekologického usuzování, jehož předmětem je přenesení vzorců volebního chování z agregované na individuální úroveň (Robinson 1950; Kostelecký, Čermák 2003). Jestliže mezi územními zisky politické strany a volební účastí panuje vysoká korelace, nemusí to znamenat, že podpora dané strany roste s tím, jak roste volební účast. Zcela korektní interpretace těchto výsledků by měla být, že tyto strany mají vyšší volební podporu v těch oblastech, kde je vyšší volební účast (Linek 2007). Agregovaná data však přes svá omezení nabízejí výsledky a interpretace, jež mohou být užitečné, a proto mám za to, že tento text nepředstavuje pouze „korelační cvičení“.

Po nastínění teoreticko-metodologické perspektivy textu bych měl věnovat několik poznámek operacionalizaci nezávislých i závislé proměnné. Klíčový prediktor, kterým bude vždy volební účast, chápu jako procento registrovaných voličů, kteří ve volbách do Poslanecké sněmovny v roce 2010 v dané jednotce odevzdali svůj hlas. Cílová proměnná se bude v níže prezentovaných výstupech lišit. Vždy půjde o procentuální podíl hlasů pro určitou politickou stranu ${ }^{17}$ (popř̀ konglomerát stran) na platných hlasech ve vybrané jednotce a volbách. Za jednotku analýzy byly vybrány obce Středočeského a Moravskoslezského kraje. Celkem analýza pokrývá 1444 obcí, přičemž 1145 z tohoto počtu spadá do Středočeského a zbylých 299 do Moravskoslezského kraje.

\footnotetext{
${ }^{16}$ Lineární regrese je technikou analýzy dat založenou na Pearsonově korelačním koeficientu.

${ }^{17}$ Beru v úvahu pouze strany, které v daných volbách získaly zastoupení v Poslanecké sněmovně, tj. ODS, ČSSD, TOP09, KSČM a VV.
} 
Efekt volební účasti na zisky stran bude kontrolován za pomoci velikosti populace a míry nezaměstnanosti. ${ }^{18}$ Velkou výhodou těchto faktorů je jejich dostupnost za jednotlivé obce. Kostelecký (2005: kap. 2 a 3) navíc prokázal, že v českém kontextu disponují poměrně silným významem - v populačně malých obcích bývá vyšší volební účast než ve větších a míra nezaměstnanosti je záporně korelována se zisky „fiskálně konzervativních“ stran (srov. Saglie et al. 2012). Uvedené faktory využívám pro vytvoření komplexnějšího regresního modelu, který ukáže, jak se mění vztah mezi stěžejní vysvětlující proměnnou (volební účastí) a závislou proměnnou (zisk strany) při uplatnění alternativních vysvětlení voličské prŕízně pro určitou stranu/blok.

Nejobtížnější úkol v rámci této kapitoly tkví v nutnosti usadit strany na pravolevé škále, aby následně mohly být přidruženy $\mathrm{k}$ pravici nebo levici. Kromě zmíněné studie Kosteleckého (2005: 52-54) se o približzení konstelace stran $\mathrm{v}$ politickém prostoru $\mathrm{v}$ minulosti pokoušela rovněž autorská dvojice Chytilek - Eibl (2011). Vzhledem k době sběru dat ale ani jedna z citovaných prací nemohla reflektovat založení TOP09 a vzestup VV. Ve volbách 2010 nicméně oba subjekty získaly zastoupení ve Sněmovně, a nelze je tudíž v dalších odstavcích opomenout. Jestliže připustíme, že u trrí zavedených stran, které jsou předmětem zkoumání, nedošlo od analýzy Chytilka s Eiblem k výraznějším ideologickým posunům - a tedy nalevo od středu jsou lokalizovány ČSSD a KSČM (druhá jmenovaná přitom spadá do extrémního sektoru), zatímco ODS leží napravo -, zbývá v rámci jednorozměrného zjednodušení usadit TOP09 a VV. U TOP09 se situace zdá být relativně přehledná. Subjekt lze poměrně věrohodně začlenit do skupiny liberálně-konzervativních stran, a můžeme tedy tvrdit, že konverguje k pravé straně spektra (Eibl 2010; Černoch et al. 2011: 25-30). Mnohem více rozporů plodí VV. Působení strany by se snad mohlo dát do souvislosti s konceptem (pravicového) populismu (Mareš 2011; srov. Havlík 2010). Zařazení VV k populistickým subjektům může budit jisté kontroverze, nicméně zde budeme takovou klasifikaci do značné míry respektovat. Vědom si všech problémů, které přidělení jednomu z ideologických pólů spektra přináší, začleňuji VV „podmínečně“ do skupiny pravicových stran, avšak zároveň se zdržuji lokalizace daného subjektu na okraj pravé části spektra.

\section{Analýza a výsledky}

V následující kapitole prezentuji výstupy regresní analýzy, v níž jako závislá proměnná vystupuje zisk konkrétního politického uskupení a nezávislou proměnnou tvoří volební účast a kontrolní faktory. Další pasáže textu ukazují, že jak ve Středočeském, tak Moravskoslezském kraji je dopad míry volební participace podobný; statisticky významné nestandardizované koeficienty B mají vždy u vybrané strany stejný směr. Přestože tak vybrané regiony vykazují zřetelné odlišnosti v socioekonomické i politické dimenzi, na vztah mezi volební účastí a podporou stran by tato skutečnost zřejmě neměla mít podstatnější vliv. V tabulce 2 (viz níže) prezentuji celkem šestnáct samostatných regresních modelů, které odhadují vztah mezi volební účastí a volební podporu uvedených stranických formací v obcích Středočeského a Moravskoslezského kraje při kontrole velikosti populace a míry nezaměstnanosti.

\section{Středočeský kraj}

\footnotetext{
18 Velikost populace měřím počtem obyvatel, kteři žili na území obce k 1. lednu 2010. V modelech počítám s přirozeným logaritmem této hodnoty. Míra nezaměstnanosti představuje procentuální podíl registrované nezaměstnanosti za duben 2010.
} 
V prvé řadě musím zdůraznit, že míra vysvětlené variance volební podpory ve Středočeském kraji je poměrně nízká - „nejlepšiı“ model (č. 7) dokáže objasnit jen $25 \%$ rozptylu závislé proměnné. Hodnoty koeficientu determinace jsou celkově o něco vyšší pro modely týkající se stranických bloků než pro jednotlivé strany. Na základě informace o problematické explanační síle modelů není možné přehlédnout skutečnost, že modely poskytují jen velmi hrubou představu o reálném fungování vztahu mezi závislou a nezávislou proměnnou, a proto nedává větší smysl interpretovat přesné hodnoty nestandardizovaných koeficientů. V následujících odstavcích se tak budu zabývat pouze směrem vztahu, na nějž hodnoty z horní poloviny tabulky 2 poukazují.

Hodnocení závislosti volební podpory na volební účasti i přes nízkou explanační sílu modelů přináší pozoruhodná zjištění. Předně, pro oba liberálně-konzervativní subjekty ve stranickém spektru (ODS a TOP09) platí, že v místech s vyšší mírou volební participace jsou jejich volební zisky vyšší (k tomu viz také Šaradín 2004). Pozitivní závislost lze identifikovat rovněž u bloku pravicových uskupení. Uvedené výsledky by tak mohly přinést podporu hypotéze o mobilizaci proti levici $\left(\mathrm{H}_{1}\right)^{19}$, která převrací původní vztah, jehož platnost byla testována $\mathrm{v}$ prostředí západních demokracií. Atmosféra postkomunismu se tedy, zdá se, výrazně podepisuje na stranických konsekvencích volební účasti. To je ostatně patrné i při pohledu na nestandardizované koeficienty $\mathrm{v}$ modelech pro levicová uskupení. Ve Středočeském kraji pro ČSSD, KSČM i levicový konglomerát platí, že v územních jednotkách s vyšší volební účastí jsou tyto formace $z$ hlediska podpory slabší. Shrnuto do jedné věty, na základě analýzy pro Středočeský kraj se daří přinést podporu hypotéze $\mathrm{H}_{2}$. Z porovnání hodnot koeficientů u sociálních demokratů a komunistů rovněž vyplývá, že negativní efekt je o něco robustnější pro krajní levici.

Krátké zastavení vyžadují ještě dva faktory, jimiž jsem kontroloval vliv volební účasti na podporu stranicko-politických aktérů. Modely, s výjimkou toho pro VV, poměrně jasně prokazují, že v populačně větších obcích existuje lepší půda pro prosazování pravicových idejí. U nezaměstnanosti je taktéž patrná vysoká míra konzistence u výsledků aktérů z řad pravice, resp. levice. V obcích s vyšším podílem lidí bez pracovního uplatnění disponují vyšší podporou subjekty z levé části spektra, zatímco tam, kde je nezaměstnaných méně, se víc hlasuje pro pravicová uskupení.

\footnotetext{
${ }_{19}$ Otázkou ovšem je, jak interpretovat model 5 pro VV. Ten nevysvětluje prakticky žádnou variabilitu v podpoře této strany $\left(\mathrm{R}^{2}=0,003\right)$ a zároveň statisticky nevýznamná hodnota nestandardizovaného koeficientu naznačuje, že volební podpora strany je necitlivá na působení volební účasti. Dle mého soudu tento model nezpochybňuje platnost hypotézy $H_{1}$, nebot’ - jak jsem se snažil sdělit výše - VV nepředstavuje zcela autentickou pravici.
} 
Tabulka 2. OLS regresní modely

\begin{tabular}{|c|c|c|c|c|c|c|c|c|}
\hline Středočeský kraj & Model 1 & Model 2 & Model 3 & Model 4 & Model 5 & Model 6 & Model 7 & Model 8 \\
\hline Strana & ODS & ČSSD & TOP09 & KSČM & $\mathrm{VV}$ & Pravice & Pravice bez VV & Levice \\
\hline \multirow[t]{2}{*}{ Konstanta } & $-3,541$ & $42,244 * * *$ & $-11,492^{* * *}$ & $33,958^{* * *}$ & $12,401 * * *$ & $-2,633$ & $-15,034^{* * *}$ & $76,202 * * *$ \\
\hline & $(2,416)$ & $(2,714)$ & $(2,280)$ & $(2,257)$ & $(1,467)$ & $(3,886)$ & $(3,649)$ & $(3,729)$ \\
\hline \multirow[t]{2}{*}{ Volební účast } & $0,266^{* * *}$ & $-0,220 * * *$ & $0,278^{* * *}$ & $-0,237 * * *$ & $-0,011$ & $0,533 * * *$ & $0,544 * * *$ & $-0,458^{* * *}$ \\
\hline & $(0,027)$ & $(0,030)$ & $(0,025)$ & $(0,025)$ & $(0,016)$ & $(0,043)$ & $(0,040)$ & $(0,041)$ \\
\hline \multirow[t]{2}{*}{ Velikost populace $(\ln )$} & $1,550^{* * *}$ & $-1,281 * * *$ & $1,621 * * *$ & $-1,230^{* * *}$ & 0,000 & $3,171 * * *$ & $3,172^{* * *}$ & $-2,511 * * *$ \\
\hline & $(0,171)$ & $(0,192)$ & $(0,162)$ & $(0,160)$ & $(0,104)$ & $(0,276)$ & $(0,259)$ & $(0,264)$ \\
\hline \multirow[t]{2}{*}{ Nezaměstnanost } & $-0,169 * * *$ & $0,251 * * *$ & $-0,174 * * *$ & $0,234 * * *$ & $-0,071 * *$ & $-0,415^{* * *}$ & $-0,344 * * *$ & $0,431 * * *$ \\
\hline & $(0,047)$ & $(0,053)$ & $(0,044)$ & $(0,044)$ & $(0,028)$ & $(0,075)$ & $(0,071)$ & $(0,072)$ \\
\hline Adj. $\mathrm{R}^{2}$ & 0,155 & 0,100 & 0,184 & 0,156 & 0,003 & 0,237 & 0,253 & 0,203 \\
\hline Moravskoslezský kraj & Model 9 & Model 10 & Model 11 & Model 12 & Model 13 & Model 14 & Model 15 & Model 16 \\
\hline Strana & ODS & ČSSD & TOP09 & KSČM & $\mathrm{VV}$ & Pravice & Pravice bez VV & Levice \\
\hline \multirow[t]{2}{*}{ Konstanta } & $-5,467$ & $51,985^{* * *}$ & $-1,498$ & $24,033^{* * *}$ & $12,961 * * *$ & 5,996 & $-6,965$ & $76,018^{* * *}$ \\
\hline & $(3,594)$ & $(5,382)$ & $(2,582)$ & $(4,243)$ & $(2,808)$ & $(6,102)$ & $(4,933)$ & $(6,304)$ \\
\hline \multirow[t]{2}{*}{ Volební účast } & $0,256^{* * *}$ & $-0,359 * * *$ & $0,156^{* * *}$ & $-0,186^{* * *}$ & 0,010 & $0,422^{* * *}$ & $0,412^{* * *}$ & $-0,545^{* * *}$ \\
\hline & $(0,038)$ & $(0,057)$ & $(0,027)$ & $(0,045)$ & $(0,030)$ & $(0,065)$ & $(0,052)$ & $(0,067)$ \\
\hline \multirow[t]{2}{*}{ Velikost populace (ln) } & $0,919 * * *$ & $-0,224$ & $0,386^{* * *}$ & $-0,765^{* * *}$ & $-0,154$ & $1,151^{* * *}$ & $1,304 * * *$ & $-0,989 * * *$ \\
\hline & $(0,202)$ & $(0,303)$ & $(0,145)$ & $(0,239)$ & $(0,158)$ & $(0,343)$ & $(0,277)$ & $(0,354)$ \\
\hline \multirow[t]{2}{*}{ Nezaměstnanost } & $-0,096^{*}$ & $-0,045$ & $-0,108^{* * *}$ & $0,534 * * *$ & $-0,027$ & $-0,231 * *$ & $-0,204 * *$ & $0,489 * * *$ \\
\hline & $(0,058)$ & $(0,087)$ & $(0,042)$ & $(0,068)$ & $(0,045)$ & $(0,098)$ & $(0,079)$ & $(0,102)$ \\
\hline Adj. $\mathrm{R}^{2}$ & 0,276 & 0,143 & 0,237 & 0,412 & 0,004 & 0,271 & 0,355 & 0,418 \\
\hline
\end{tabular}

Zdroj: Autor. Pozn.: Závislou proměnnou je zisk politické strany uvedené pod názvem modelu. Hodnoty odpovídají nestandardizovaným koeficientům B, v závorkách je uvedena standardní chyba. Statistická významnost: *** - signifikantní na 0,01; ** - signifikantní na úrovni 0,05; * signifikantní na úrovni 0,1. 


\section{Moravskoslezský kraj}

Dalších osm regresních modelů v tabulce 2 (modely ve spodní polovině tabulky označené číslem 9 až 16) se zabývá situací v Moravskoslezském kraji. V porovnání se Středočeským krajem dokáží tyto modely vysvětlit větši podíl variability ve volební podpoře politických stran - hodnoty koeficientu determinace se blíží až k $42 \%$. Stejně jako v př́padě středních Čech se ukazuje nejasná pozice VV ve stranicko-politickém spektru; model 13 tedy vzhledem k nízkým hodnotám $\mathrm{R}^{2}$ a nesignifikantním koeficientům nijak neobjasňuje mnou zkoumaný příčinný vztah. Jestliže budu opět hodnotit, do jaké míry regresní modely naplňují vstupní hypotézy, je třeba primárně uvést, že se i na př́padě Moravskoslezského kraje prokazuje důležitost komunistického dědictví, jež dává podporu pro úvahy o mobilizaci proti levici. Jinými slovy se prokázalo, že v místech s vyšší mírou volební participace se daři pravicovým stranám (nepočítaje VV), kdežto strany levicové ztrácejí. Tím pádem lze znovu podpořit jak hypotézu $\mathrm{H}_{1}$, tak $\mathrm{H}_{2}$. Oproti výstupům analýzy pro Stř́edočeský kraj ovšem neplatí, že by negativní asociace byla silnější pro krajní levici než pro levici umírněnou.

Ani v př́ípadě Moravskoslezského kraje nebudu opomíjet pohled na působení alternativních vysvětlení volební podpory jednotlivých politických stran. Spodní polovina tabulky 2 přináší informaci o tom, že pro volební zisky stranických formací v Moravskoslezském kraji není lhostejné, jak velká je komunita, v níž voliči žijí. Opět platí, že čím větší velikost populace, tím vyšší volební zisky pravicových stran. I přes statisticky nevýznamný koeficient u ČSSD v modelu 10 pak tabulka rovněž dokáže přinášet podporu tvrzení, že levicové strany jsou ve větších územních jednotkách slabší. U nezaměstnanosti lze identifikovat poměrně zásadní rozdíl oproti Středočeskému kraji, který se týká levicových stran. Při interpretaci modelů je třeba zdůraznit, že existuje zřretelná odlišnost efektu u ČSSD a KSČM. Zatímco u sociálních demokratů nebyl prokázán jakýkoli vliv nezaměstnanosti, $\mathrm{v}$ př́padě komunistů jde o velmi silný efekt tohoto faktoru. Čili pro Moravskoslezský kraj je př́značné, že v územních jednotkách s vysokou nezaměstnaností je silně preferovanou stranou KSČM, ovšem ČSSD ne.

\section{Závěr}

$\mathrm{Na}$ účast ve volbách bývá obvykle nazíráno jako na závislou proměnnou. Jedná se tedy o fenomén, který má být vysvětlen, a to prostřednictvím aplikace různorodých př́stupů, jejichž bází může být ohled na sociální status, politické motivace, členství v organizacích či institucionální nastavení (viz Norris 2002). Tato studie ovšem chápala volební participaci úplně opačně - jako faktor, jenž má vysvětlovat podobu stranických soustav. V mém případě se jednalo o vysvětlení stranické konfigurace $\mathrm{v}$ podmínkách České republiky. S ohledem na živou zkušenost jejích obyvatel s nedemokratickým režimem jsem oproti převážné většině dosavadní literatury ověřoval předpoklad o tom, že v prostředí vyšší volební účasti budou bonifikovány strany pravice, zatímco strany levice budou na dané atmosféře tratit. Jinými slovy, se jedná o určitý druh mobilizace proti levici, která je v postkomunistickém prostoru ve světle nedemokratického období po druhé světové válce vnímána s určitým despektem. Běžně se přitom ve studiích tohoto typu uvádí opak, a to na bázi ospravedlnění, že vyšší účast znamená, že se k volebním urnám dostaví i příležitostní voliči s nižším sociálním statusem, jejichž preference jsou převážně levicové.

Pro testování hypotéz jsem využil - přes všechny problémy s tím spojené - agregovanou úroveň a regresní modely. Za př́pady byly uvažovány obce ze dvou velmi různorodých krajů ČR, Středočeského a Moravskoslezského; předmětem zkoumání byly volby do Poslanecké sněmovny 
v roce 2010. Bylo zjištěno, že výše popsané vztahy se v obou krajích velmi podobají a zároveň naplňují „nekonvenčni““ předpoklady. Lze tedy konstatovat, že míra volební participace $\mathrm{v}$ jednotlivých obcích je pozitivně asociována se zisky autenticky pravicových subjektů, ODS a TOP09. U umírněné a radikální levice naopak byla vyšší účast spojena s nižší volební podporou těchto subjektů.

\section{Literatura}

Aguilar, E.E. - Pacek, A.C. (2000): Macroeconomic Conditions, Voter Turnout, and the Workingclass/Economically Disadvantaged Party Vote in Developing Countries, Comparative Political Studies roč. 33, č. 8, s. 995 - 1017. DOI 10.1177/0010414000033008001

Blažek,J. - Csank, P. (2007): Nová fáze regionálního rozvoje v ČR? Sociologický časopis, roč. 43, č. 5, s. $945-965$.

Bohrer, R. E. - Pacek, A. C. - Radcliff, B. (2000): Electoral Participation, Ideology, and Party Politics in Post-Communist Europe, Journal of Politics, roč. 62, č. 4, s. 1161-1172.

Brady, H. E. - Verba, S. - Schlozman K. L. (1995): Beyond Ses: A Resource Model of Political Participation, American Political Science Review, roč. 89, č. 2, s. 271-294. DOI: 10.2307/2082425

Campbell, A. et al. (1960): The American Voter, New York, John Wiley \& Sons.

Citrin, J. - Schickler, E. - Sides, J. (2003): What if Everyone Voted? Simulating the Impact of Increased Turnout in Senate Elections, American Journal of Political Science, roč. 47, s. 75-90. DOI: 10.1111/1540-5907.00006

Čechák, V. (2006): Metodologicko-filozofické aspekty díla J. S. Milla, in: Loužek, M. (ed.): John Stuart Mill. Dvě stě let od narození, Praha, Centrum pro ekonomiku a politiku, s. 43 - 54.

Černoch, F. et al. (2011): Political Parties and Nationalism in Visegrad Countries, Brno, Masaryk University.

Český statistický úřad. (2011): Analýza regionálních rozdílů v ČR, ročník 2010. (http://www.czso.cz/csu/2010edicniplan.nsf/t/170033A89D/\$File/137010a.pdf) [cit. 10.2. 2012]

Český statistický úřad. (2012): Veřejná databáze. (http://vdb.czso.cz/vdbvo/uvod.jsp) [cit. 10.2. 2012]

DeNardo, J. (1980): Turnout and the Vote: The Joke's on the Democrats, American Political Science Review, roč. 74, č. 2, s. 406-420.

Eibl, O. (2010): Volební programy, in: Balík, S. (ed.): Volby do Poslanecké sněmovny v roce 2010, Brno, Centrum pro studium demokracie a kultury, s. $69-96$.

Eibl, O. et al. (2009): Krajské volby 2008, Brno, Centrum pro studium demokracie a kultury.

Finseraas, H. - Vernby, K. (2011): A Mixed Blessing for the Left? Early Voting, Turnout and Election Outcomes in Norway, text prezentovaný na Výročním setkání Evropské politologické asociace, Dublin, červen 2011.

Fisher, S. D. (2007): (Change in) turnout and (change in) the left share of the vote, Electoral Studies, roč. 26, s. 598-611. DOI: 10.1016/j.electstud.2006.10.006

Gijsbeerts, M. - Nieuwbeerta, P. (2000): Clas Cleavages in Party Preferences in the New Democracies in Eastern Europe: A comparison with Western democracies, European Societies roč. 2, č. 4, s- $397-$ 430. DOI: $10.1080 / 14616690020014343$

Grofman, B. - Owen, G. - Collet, C. (1999): Rethinking the Partisan Effects of Higher Turnout: So What's the Question?, Public Choice, roč. 99, č. 3-4, s. 357-376.

Hajnal, Z. - Trounstine, J. (2005): Where Turnout Matters: The Consequences of Uneven Turnout in City Politics, Journal of Politics, roč. 67, č. 2 , s. 515-535. 
Hansford, T. G. - Gomez, B. T. (2010): Estimating the Electoral Effects of Voter Turnout, American Political Science Review, roč. 104, č. 2, s. 268-288. DOI: 10.1017/S0003055410000109

Havlík, V. (2010): Politické strany a jejich systém v letech 2006 - 2010, in: Balík, S.: Volby do Poslanecké sněmovny v roce 2010. Brno: Centrum pro studium demokracie a kultury, s. 11 - 38.

Hendl, J. (2009): Přehled statistických metod: Analýza a metaanalýza dat, Praha, Portál.

Hloušek, V. - Kopeček, L. (2005): Konfliktní linie v současné české a slovenské politice: mezi stabilitou a změnou. Working Paper č. 10. Brno: Mezinárodní politologický ústav.

Hloušek, V. - Kopeček, L. (2010): Politické strany. Původ, ideologie a transformace politických stran v západní a střední Evropě, Praha, Grada.

Chytilek, R. - Eibl, O. (2011): České politické strany v politickém prostoru, Sociologický časopis, roč. 47, č. 1, s. 61-88.

Illner, M. - Kostelecký, T. - Patočková, V. (2007): Jak fungují kraje - př́spěvek k hodnocení výkonu krajských vlád, Sociologický časopis, roč. 43, č. 5, s. $967-992$.

Knutsen, O. (2006): Class Voting in Western Europe: A Comparative Longitudinal Study, Lanham, Lexington Books.

Kostelecký, T. (2005): Political Behavior in Metropolitan Areas in the Czech Republic between 1990 and 2002 - Patterns, Trends, and the Relation to Suburbanization and Its Socio-Spatial Patterns, Praha: Sociologický ústav AV ČR.

Kostelecký, T. - Čermák, D. (2003): Výběrová šetření a analýza agregátních dat - diskuse na téma použitelnosti různých prístupů $\mathrm{v}$ komparativních analýzách politického chování, Sociologický časopis, roč. 39, č. 4, s. $529-550$.

Kouba, K. (2007): Prostorová analýza českého stranického systému. Institucionalizace a prostorové režimy, Sociologický časopis, roč. 43, č. 5, s. $1017-1037$.

Kubát, M. (2003): Postkomunismus a demokracie. Politika ve středovýchodní Evropě, Praha, Dokořán.

Lijphart, A. (1971): Comparative Politics and Comparative Method, American Political Science Review, roč. 65 , č. 3, s. 682-693. DOI: 10.2307/1955513

Lijphart, A. (1997): Unequal Participation: Democracy's Unresolved Dillema, American Political Science Review, roč. 91, č. 1, s. 1-14. DOI: 10.2307/2952255

Linek, L. (2007): Vliv volební účasti na zisky jednotlivých politických stran: př́pad voleb do Poslanecké sněmovny v roce 2006, Politologický časopis, roč. 14, č. 3, s. 205-223.

Linek, L. (2012): Vliv volební účasti na zisky politických stran ve volbách do Poslanecké sněmovny, Acta Politologica roč. 4, č. 1, s. 1-17.

Linek, L. - Lyons, P. (2007): Zdroje a motivace volební účasti, in: Lebeda, T. et al.: Voliči a volby 2006, Praha, Sociologický ústav AV ČR, s. 63 - 86.

Lutz, G. - Marsh, M. (2006): Introduction: Consequences of low turnout, Electoral Studies, roč. XX, s. 1 $-9$.

Mareš, M. (2011): Czech Extreme Right Parties An unsuccessful story, Communist and Post-Communist Studies, roč. 44, č. 4, s. 283 - 298. DOI: 10.1016/j.postcomstud.2011.10.007

Matušková, A. (2006): Volební kampaň 2006: Nástup politického marketingu do České republiky, in: Čaloud, D. et al. Volby do Poslanecké sněmovny v roce 2006, Brno, Centrum pro studium demokracie a kultury, s. $62-88$.

Nagel, J. - McNulty, J. (1996): Partisan Effects of Voter Turnout in Senatorial and Gubernatorial Elections, American Political Science Review, roč. 90, č. 3, s. 780-793.

Navrátil, V. (2010): Volební geografie a parlamentní volby v České republice 2010, Evropská volební studia, roč. 5 , č. 1 , s. $183-205$. 
Norris, P. (2002): Democratic phoenix: reinventing political activism, Cambridge, Cambridge University Press.

Pacek, A. C. - Radcliff, B. (1995): Turnout and the Vote for Left-of-Centre Parties: A Cross-National Analysis, British Journal of Political Science, roč. 25, č. 1, s. 137-143.

Pacek, A. C. - Radcliff, B. (2003): Voter participation and party group fortunes in European parliament elections, 1979-1999: A cross-national analysis, Political Research Quarterly, roč. 56 č. 1, s. 91-95. DOI: $10.1017 /$ S0007123400007109

Plasser, F. - Ulram, P. - Waldrauch, H. (1998): Democratic Consolidation in East-Central Europe, New York, St. Martins Press.

Radcliff, B. (1994): Turnout and the Democratic Vote, American Politics Quarterly, roč. 22, č. 2, s. 259276. DOI: $10.1177 / 1532673$ X9402200301

Robinson, W. S. (1950): Ecological correlations and the behaviour of individuals, American Sociological Review, roč. 15, č. 3, 351-7. DOI: 10.2307/2087176

Rose, R. (1997): Evaluating Election Turnout, in Voter Turnout from 1945 to 1997: A Global Report on Political Participation, Stockholm, International IDEA, s. 35-46.

Rose, R. (2009): Understanding post-communist transformation: a bottom up approach. New York: Routledge.

Saglie, J. - Bergh, J. - Bjorklund, T. (2012). Do Labour Parties Suffer from Declining Turnout? Evidence from Norwegian Local Elections, Local Government Studies, roč. 38, č. 2, s. 249 - 270.

SC\&C - SPSS CR. (2010): Exit Poll - závěrečná zpráva SC\&C a SPSS CR pro Českou televizi. (http://img7.ct24.cz/multimedia/documents/17/1699/169810.doc) [cit. 10.2. 2012]

Smith, M. L. - Matějů, P. (2011): Restratifikace české politiky. Vývoj třídně podmíněného volebního chování v České republice v letech 1992-2010, Sociologicky časopis, roč. 47, č. 1, s. 33-59.

Strmiska, M. et al. (2009): Volební komplexy zemí V4: Studie k pojetí víceúrovňového volebního prostoru, Brno, Centrum pro studium demokracie a kultury.

Svatošová, L. (2004): Metodologická východiska analýz regionálního rozvoje. In: Svatoš, M.-Boháčková, I. (eds.). Agrární perspektivy XIII. Praha: Česká zemědělská univerzita, s. 622-627.

Šaradín, P. (2004): Územní podpora Občanské demokratické strany ve volbách, Acta Universitatis Palackianae Olomucensis Politologica, roč. 3, s. 145-157.

Teixeira, R. (1992): The Disappearing American Voter, Washington, The Brookings Institution.

Torcal, M. - Mainwaring, S. (2003): Social Cleavages, the Anchoring of the Vote, and Party System Stability: Latin America and Western Europe. Text prezentovaný na Společné seminární schůzi Evropského konsorcia pro politologický výzkum, Edinburg, 28. březen - 2. duben 2003.

Tóka, G. (1996): Parties and Electoral Choices in East Central Europe, in: Lewis, P. - Pridham, G. (eds.): Stabilising Fragile Democracies. London: Routledge, s. 100 - 125.

Tóka, G. (2004): The impact of turnout on election outcomes in a cross national perspective, text prezentovaný na 14. Mezinárodní konferenci europeanistů organizované Radou pro evropská studia, Chicago, USA, 11.-13. 3. 2004.

Tucker, H. - Vedlitz, A. (1986): Does Heavy Turnout Help Democrats in Presidential Elections?, American Political Science Review, roč. 80, č. 4, s. 1291-98. DOI: 10.2307/1960868

Van der Eijk, C. - van Egmond, M. (2006): Effects of Low Turnout on Election Outcomes. Evidence from the European Election Studies 1989, 1994, 1999 and 2004, text prezentovaný na konferenci European Parliament Election of 2004, Lisabon, Portugalsko, 11.-14. 5. 2006.

Vlachová, K. (2003): Dynamika pozitivní a negativní stranické identifikace v České republice, Sociologický časopis, roč. 39, č. 4, s. 487-508.

Vráblíková, K. (2009): Politická participace a její determinanty v postkomunistických zemích, Sociologický časopis, roč. 45 , č. 5, s. $867-897$. 